\title{
Positioning the performance of public service. When management tools are in conflict : the case of urban water management
}

Marie Tsanga Tabi, U.M.R Cemagref-ENGEES “Management of Public Services”, 1 quai Koch 67070 Strasbourg - marie.tsanga@engees.u-strasbg.fr ${ }^{1}$,

\begin{abstract}
:
On the basis of action research performed in the field of urban water management, we report the conflict occurring between a new management tool introduced in a public service and the pre-existing tool, in order to examine how the actors involved question the content and pertinence of the performance of their organisation.
\end{abstract}

Key words : public performance, managerial instrumentation, public services, water supply.

\section{Introduction:}

Over the last few years, the quest for improving performance in the public sector has become a new paradigm and the importance of the implementation of the tools used to achieve this goal has reached the point where certain authors have named them the "invisible pilots of public action" (Lorrain D., 2005). As early as 1995, Pollit C. and Bouckaert G. in their work on improving quality in European public services, qualified the dissemination of such practices as an "invasive phenomenon".

In the sector of French public water utilities, the "performance phenomenon" has spread remarkably quickly since the beginning of the 1990s in a context in which rocketing water prices and the resulting controversy were to take centre stage. Consequently, performance indicators had to tangibly demonstrate the efficiency of the management of public water services. The first national standard (Standard NF P15 "Service to the User") came into being in 2000 while a second series of three standards published by the International Standards Organisation ${ }^{2}$ appeared several years later (December 2007).

This is the framework in which we situate our premise. Rather than focusing on performance indicators, it reports the conflict between new and existing performance management tools in a large urban public service ${ }^{3}$. We use as our basis the conflict occurring between the new $\mathrm{ABC}^{4}$ tool introduced in the water service and the pre-existing tool, the quality management approach, to examine how the actors involved question the content of the performance of their organisation.

To give substance to and facilitate understanding of our premise, we set the stage by clarifying the status of performance management tools in the specific context of major urban water services (part I).

We then focus on the subsequent conflict between tools and in particular present the main results of the evaluation performed on the usefulness and meaning of public action in the framework of the total quality management approach. We shall see how, beyond the apparently neutral implementation of the quality tool, the latter actually contributes towards consolidating the technical rationales inherent in managing the public water service (part II). In parallel, we discuss two basic questions raised by this conflict:

- first, that of the rationales embodied by management tools and their link with perceptions of public action,

- then that of the content of the performance of public services in a context of increased implementation of new tools intended to facilitate public action.

\footnotetext{
${ }^{1}$ The author thanks the reviewers for their comments which helped in defining the premise more clearly.

${ }^{2}$ Standards ISO 24510, 24511 and 24512 relating to performance management and the management of public water and sewage services.

${ }^{3}$ The case in question concerns the public water supply service of Greater Nantes , the "Régie Communautaire de l'Eau" (RCE).

${ }^{4}$ A.B.C. is the English acronym for "activities based costing” and translated into French by ”approche des coûts par les activités". The tool in question is currently being integrated.
} 
While referring to the literature relating to the issue of management tools in the public sector, our analysis is based on the works in progress of an action-research programme carried out jointly by our team and the public water service studied. The objectives and the approach of this research are presented in box 1

\section{Box 1 : The stakes, objectives and research-action method organised in the Greater Nantes public water service}

The territory covered by the Greater Nantes public water service has a population of 595,000, and serves 24 municipalities that form the largest urban area in western France. Three operators share the management of the city's water service:

- $\quad$ the public water supply service (RCE) set up more than century ago and which supplies $75 \%$ of the population with water;

- Véolia and Saur, two French private companies that serve the remaining 25\% of the population.

The senior management of the public water service composed of 47 employees, acting on behalf of the political authority, oversees and organises the public water service and as such is responsible for strategic management and auditing the three operators.

The action-research programme set up between our research team and the senior management of the public water service in 2006 intervenes in a context of emerging new social and economic stakes in public water management that emphasise the limits of the traditional model of the "technical citadel" specific to the management of major urban services. Designed jointly with operational actors, this 4-year programme which involves only the public operator, pursues the twofold objective of responding to the concerns of managerial changes and enhancing fundamental knowledge in human and social sciences (E. Christen-Gueissac, 2006). In particular, one of the main missions of this action-research aims at establishing a new organisation chart and approach to performance management by introducing an as yet inexistent cost measurement tool. It is the works relating to this project in particular that have inspired this article. A second project, linked to the first, seeks to identify the public values capable of forming a new frame of reference for evaluating local public action. From the scientific viewpoint, the aim is to propose a conceptual model for assessing the performance of public services intended to satisfy essential community needs. This model should take better account of the new stakes of the society in which these organisations function.

This research is collective and based on a process of participatory action-research in which the actors and researchers jointly formulate the premise and the objectives of the research while being committed to collaboration and consultation. The method implemented borrows from constructivist methods (in the meaning given by K. Lewin, 1951, and Alex Mucchielli, 1991). It is based on the definition of a research strategy and protocol that place emphasis on the concrete situation giving rise to the problem (in our case this entails moving outside a narrow technocentric appraisal of performance), it takes place within real social relationships (daily management), and it is linked to a project of managerial innovation (the introduction of a tool capable of analysing a new dimension of performance).

Although the ABC (Activity Based Costing) method was chosen for the new management tool, the actionresearch did not aim to build the tool with the technical standpoint in mind $^{5}$. Rather, the aim was to understand the dynamics of the changes occurring in the perceptions of performance of the actors brought about by reshaping the model of the key of activities involved. Another aim was to study the social impact of the tool on the system. Indeed, a cost indicator is not only a simple, neutral measurement of an activity. Such a tool expresses a strategic intention liable to modify the interplay and relations between the actors of the organisation and the current perceptions of the performance concerned. This is why, through participatory observation, one of the objectives consisted precisely in observing the channels and effects of these transformations and analysing the procedures of confrontation/links between the actors' partial and biased perceptions. The research was carried out according to a protocol composed of different steps including planning (objectives, resources, timing), data collection, debriefing sessions and reflexive feedback on the results and how the research proceeded. At operational level, a research supervision group composed of actors from the senior management of the public water service ${ }^{6}$ and researchers from our team managed and coordinated the research. The "practical" phase gave rise to 15 work sessions with different groups of employees of departments, 2 confrontations with the quality unit, 3 collective feedback and discussion workshops bringing together the action-research supervision group, and senior and middle management.

Our premise is based on the analysis of our research diary, and particularly the field observations of, and the

\footnotetext{
${ }^{5}$ The tool was built in the framework of a research partnership contract between the public water service and another research organisation.

${ }^{6}$ In this case, the forward planning and programming manager and the operations and water consumption monitoring manager.
} 
reflexive feedback from the actors. We also used the internal documentation of the department as well as the 2008 evaluation report of the quality certification organisation.

\section{I: Status and role of management tools in urban water supply services}

The management of public water services combines two types of management tool: the first implies the management of a public service as a technical object, whereas the second more recent type situates the public service as a means for public action.

\subsection{The management tools of the "technical citadel"}

The management of large urban public services (water, sewage, electricity, etc.) belongs to a specific world that we qualified several years ago as a "technical citadel” (Marie Tsanga Tabi, 2003). It is not possible to understand the issue of management tools without taking this specific characteristic into account.

Originally, the status of the management tools implemented in public water services was mainly based on satisfying the numerous regulations that generally influence the management of public organisations. In the case of the public water service studied here, the legal framework, and technical and accounting rules mould the service's technical and financial operation, acting as instruments designed to rationalise the service's activities. However, the dynamics of rationalising action by management tools have a concrete impact on the levels of health and engineering, areas where the functional, organisational and public health constraints linked to supplying water via the public network fulfil a specific role. In the modern version of water supply, the management of the "network" as a group of technical infrastructures permitting the transport of water to users' homes, relies on implementing tools to automate and regulate the operation of the network: tools for monitoring the chain comprised by the production process, water transport and distribution, multiplex transmission of production management data, metric instruments for measuring and monitoring the quality of the water circulating in the network in real time and so forth. One of the goals ensured by these tools is that of securing the water supply and ensuring its continuity throughout the chain, especially in cities and towns, as risk prevention and management are inherent consequences of this mode of operation.

Furthermore, due to the very high amount of capital investment involved, the management of public water services calls for preventive and corrective maintenance policies as well as rehabilitation and renovation, implying truly formidable strategic and economic impacts. The pressing issue of measuring and analysing the aging of the network is far from being solved by those responsible for managing it. Tools for modelling and analysing the aging of pipes have been developed in recent years, as have geographic information systems (GIS) used to computerise the mapping of water supply networks and other different types of information related to changes affecting the system.

We are in a process of "specialised rationalisation" of action (Moisdon J-C., 1997) justified in terms of productive efficiency and the constitution of specific knowledge in which instrumental rationales play an important role. This form of technocentric rationalisation was to become so pervasive that it overdetermined the management of the service, thereby mirroring the "technical citadel" that, a priori, structured the vision of the organisation's performance.

This model has endured for nearly a century in the district of Nantes without being called into question by successive political and technical administrations or by the users ${ }^{7}$.

However, implementing the action research project devoted to measuring economic performance introduced a breach in this conception. In particular, during the collective debate on the new map of the organisation ${ }^{8}$, it brought to light a new dimension to performance management tools.

\footnotetext{
${ }^{7}$ This local and "calmed" context of public water service management does not however reflect the pervading situation in France, characterised by the recurrent debate on the geographic imbalance of water prices and their progression.
} 


\subsection{Management tools used in the public water service as a means of public action}

The history of the management of the city water service (RCE) ${ }^{9}$ of Greater Nantes is rooted in a past in which the choice for public management of this utility dates back more than a century (1895), in a general context in France where elected representatives have tended to delegate their public water services to the private sector ${ }^{10}$.

In the public service studied here, the emergence of discourse on improving performance and its instrumentation has occurred concurrently with the trend that began in the 1990s for changing the regulations governing the water sector to counteract the drifts observed with services delegated to private operators ${ }^{11}$. Whereas national debate on the private management of water rose in volume, the local management of water in Nantes found itself relatively sheltered from such criticism. The introduction in the beginning of the 1990s of management improvement instruments occurred progressively to satisfy different stakes in a continued quest for performance. Three chronological periods can be distinguished.

\section{A. Management by objectives: the first tool for specifying the finality of public action}

In a controversial national framework of unprecedented water price rises (Guellec report, 1995) ${ }^{12}$, the City of Nantes began an original approach in $\underline{1995}$ and drafted the first city water service performance contract. Faced by an increase in the local price of water resulting from the obligation to upgrade wastewater treatment to European standards, resulting in heavy investments from 1995-1998 (€76 million), and by the significant rise in the amount of fees demanded by the water authorities (effect of the water law of 1992), the service decided to act. A performance contract that above all obeyed the imperative of economic security was to be implemented for the first time by the political management in collaboration with the technical management (the municipal water service).

The managerial novelty introduced by the performance contract stems from the type of link forged between the political and technical managements in place. It signalled the emergence of an unprecedented managerial type relation between politicians and engineers: the politicians (elected representatives) set out as a prerequisite to public action a strategy for developing negotiated water policy and asserted the notion of performance objectives for its implementation. This strategy now takes the form of long term plans, especially with respect to pricing ${ }^{13}$.

Although the principle of performance implemented still covers the aspects of health and technology, the new dimension introduced is that the technical goals are validated at political level in the form of an economic plan aimed at controlling water prices over a period of six years.

\section{B. The implementation of the quality management tool}

In 1997, total quality management was introduced as a new performance management tool applied to the Nantes public water service. The goals formulated prior to its implementation were included in

\footnotetext{
${ }^{8}$ Map of the activities subcontracted to an external partner and drawn up according to the ABC approach in the framework of different working sessions associating the employees of the service.

${ }^{9}$ The notion of Régie Communauté de l'Eau (RCE) in France describes municipal management that co-exists at national level with management delegated to the private sector.

${ }^{10}$ The private management of water concerns almost $3 / 4$ of the French population.

${ }^{11}$ The Sapin law no. 93-122 of 29 January 1993 relating to the prevention of corruption, economic transparency and public procedures; the Barnier law no. 95-101 of 2 February 1995 relating to strengthening environmental protection; the Mazeaud law no. 95-127 of 8 February 1995 relating to public contracts and delegations of public services.

${ }^{12}$ Guellec, A. (1995). The price of water: from explosion to control? Assemblée Nationale. Information report 2342.

${ }^{13}$ Whereas up to then the municipality formulated its budgets in line with management considered annually.
} 
the first performance contract. Indeed, although the impact of the performance contract on the price of water (annual increase of 3.6\%) did not lead to friction, the actors became aware that one of the arguments in favour of this policy invoked a dimension hitherto absent from debate: taking the user into account. Thus the hypothesis that setting up a quality improvement approach would be the ideal means for taking the user into account was formulated. An ISO 9001 type quality management system was set up and managed by a quality team.

In reality, there is nothing new about the issue of quality in water management. In Greater Nantes, the very poor quality of the water from the Loire river ${ }^{14}$, the chief source of supply for the LoireAtlantique region, obviously has a structural impact on the problem of "quality" dealt with by the service. The challenge of supplying and purifying water is just as cogent now as it was at the beginning of the $19^{\text {th }}$ century ${ }^{15}$. It should be recalled that controlling water quality ${ }^{16}$ is subject to very strict regulations applicable throughout the operation of the organisation.

What is more, the stakes of improving "quality" in this case do not imply the quality of the final product but that of management and its relationship with the user, who is considered as the poor relative of public water service management in general. Firstly, from a formal standpoint, the technical network superposes the relation with the user and places the public water service in a man-technical system relation (Tsanga Tabi M., 2003) rather than in one of an interpersonal service relation in the meaning of the theory of service (Gadrey J., 1995). The use and quality of water supply are barely conditioned by the user-service agent relation. Secondly, the large number of theoretical reflections dealing with the notion of service at the time seem to express a semblance of consensus regarding the idea that the "service relation" constituted one of the characteristics traits of "service"17.

The hour of glory of the quality management tool: the water service obtained its first quality label in 2001, which was extended to a security label in 2004. In 2005, the administration participated in the Pays de la Loire EFQM management competition and was awarded a prize for the organisation of its quality-security system. Since 2007, the service has undertaken to incorporate the environment in its quality system.

Its impact on the improvement of the service's performance is real. The most significant positive effects have occurred on at least two levels:

\section{a) Setting up a participatory management culture}

Although it is not possible to characterise the management prior to the integration of the quality management tool here, all the personnel (senior management, middle management and employees) acknowledged the change in their usual roles in participating in the management of the organisation caused by the quality system. In line with this, sociologists have clearly demonstrated how the characteristics of normative writing affect social relations in organisations and impose a logic foreign to usual management rules (F. Cochoy et al, 1998). Since the method used to "draft quality procedures" implies the "executive" best placed for writing production operating procedures as well as representatives of senior management, the recommended quality procedure will be a collective effort whereas the management of the quality system will rely on the commitment of the personnel in a system aimed at optimising the process (Segrestin D. 1996). Therefore, in the experience of Greater Nantes, the description and management of 21 processes mapping the architecture of the entire organisation associates every hierarchical level of the organisation.

\section{b) Reconfiguring the management of relations with the user and setting out performance obligations}

\footnotetext{
${ }^{14}$ The pollution of the Loire linked to the discharge of urban and industrial waste water of the catchment area, was aggravated by upsurges of sludge and salt water from the estuary and the phenomenon of urban runoff water whose impact on pollution is considerable.

${ }^{15}$ In the $19^{\text {th }}$ century, when it was necessary to protect populations against the risk of epidemics.

${ }^{16}$ It is worthwhile recalling that tap water is one of the most severely controlled food products.

17 The RATP-DRI symposium titled "What use is the user?" held in 1991 focused quite specifically on this theme since its subtitle was "Service relations in the public sector".
} 
The second and most visible organisational impact of introducing quality management tools in the municipal water service was undoubtedly due to the changes that occurred in relations with users. At the outset, the service had four persons dedicated to the consumer service which counted 65,000 consumers. Reorganisations led to increasing the team to 12 employees for 115,000 consumers. ${ }^{18}$ The cost of revamping the "customer sector" was estimated at €570,000.

Although the standard declared and set out the requirements in writing, "by systematically codifying the working practices to be complied with in order to ensure quality" (AFNOR, 1996), it left the actors free to appreciate what they felt was suitable regarding the targets to be achieved and the resources to be deployed. Focusing on customer satisfaction brought into play the constraint of specifying the criteria of this satisfaction. This was followed by writing down the performance objectives and objectifying the notion of the performance to be achieved on behalf of the user. In January 2005, this reflection on the components that make up the service of supplying tap water took the form of a local charter for the public water service that summarised in 12 points the water service's commitment to the user ${ }^{19}$.

The systematisation of performing the measurements inherent in a quality system instilled a new discipline for evaluating performance, i.e. about 150 activity and performance indicators on the product, the "customer" and the management of the processes involved were measured; measurements of user satisfaction through user satisfaction surveys were performed almost every year.

In all, implementing the quality management tool reshaped and set out in stone the principles underlying the concept of performance in the public water service. We shall see the direction taken by this reshaping further on.

\section{Changes in the local landscape regarding water and the introduction of the $A B C$ tool: the problem of urban governance and the economic performance of the technical citadel}

In 2001, two major events represented a new stage in the managerial history of the Nantes municipal water service:

- the expansion of the territory covered by the water service, which grew from 6 to 24 towns following the Chevènement law, no. 99-586, of 12 July 1999 relating to consolidating and simplifying inter-municipal cooperation;

- the mix of organisational modes resulting from the above law and which brought a new category of actor into play, in particular two private operators.

The system of action was thus made more complicated and new stakes that no longer depended only on the technical rationale emerged. Henceforth the community had to define the strategy of the public water service for the whole of the new territory, develop expertise to assist decision making, organise a variety of management modes and secure the control of the operators. This new context meant new requirements in terms of urban governance: 570,000 users for a territory of 24 municipalities served by three different operators according to two different management modes ${ }^{20}$. From a political standpoint, the immediate priority was given to harmonising the prices of the service throughout the new territory. The economic result of this political aim (on average the price of water increased by $1 \%$ over the inflation rate) allowed maintaining the main financial balances while preserving social calm.

In parallel, internal reflection dwelt on the triangular relation between the system of "elected representatives-operators-users" and explained the interaction between and expectations of the stakeholders. The socio-political dimension of public action at work was posted back on the agenda

\footnotetext{
${ }^{18}$ The increase in the number of consumers was not only due to the expansion of the territory occurring in 2001; article 93 of the law relating to solidarity and urban renewal (SRU) of 13 December 2000 contributed to this increase by imposing the principle of individual water meters in blocks of flats.

${ }^{19}$ The charter can be consulted on line on http://www.nantesmetropole.fr/1140185454453/0/fiche_document/”

20 "Public management" served 65\% of the consumers of the new territory, whereas private management (private companies) served the remaining $35 \%$.
} 
and the role of the organising authority in the public decision-making process and its control of governance was reasserted.

The most recent event in this managerial history concerns the signature of a action-research agreement at the end of 2005 between a research establishment and Greater Nantes ${ }^{21}$ aimed at improving the performance of the public water service in view to "taking the global dimension into account in public action" (P. Muller, 2000). The question of knowledge that is both useful and necessary for objective public decision-making oriented towards the general interest is raised. This is the context in which the question of the cost of the public service is posed and the implementation of a dedicated ABC type tool considered.

On the theoretical level, the notion of public management as such emerged in the 1970s, followed by that of New Public Management in the 1980s, placing to the fore economic reasoning in the modernisation of public action. Recurrent criticism of the inefficiency of public organisations and their different budgetary and financial crises, led to the idea of transferring management methods applied in the private sector to the public sector. This transfer was espoused in particular by the proponents of NPM inspired by neo-conservative thinking, and which became the quasi-exclusive paradigm for reforming the public sector (C.Pollitt, 1993). The economic breeze that blew through public organisations, at least theoretically, guaranteed improved efficiency and performance of the services provided by them. It was this shift that led to the principle of Public-Private Partnership (PPP) being used as the means of introducing efficiency into the public sector. In fact this practice has been preferred by governments and local authorities over the last twenty years. Furthermore, the importance of using benchmarking, considered as the ultimate strategy in performance culture, was disseminated in different countries, but despite the fact that every country declared its utility, only a few actually put it into practice. The most interesting example can be found in Australia (Waintrop et al, 2005) where, since 1995, the Productivity Commission ${ }^{22}$ organises a comparative study of performance of the different states and territories in supplying public services.

Indeed, the management methods used to calculate costs, especially analytical accounting to measure the efficiency of public organisations, took on a polymorphic nature due to the contingencies linked to the different contexts of the measurement and cost control systems implemented (Symposium of the Institut de Management Public on 28 November 2007 on costs). Other empirical accounts report that the reality of efficiency and performance of public organisations is "embedded" in political, technical and cultural elements (P. Ughetto, 2006).

Paradoxically, in the French water sector PPP goes back a long way (the first legislation regulating the delegation of public services dates from 1880), the effects expected in terms of performance have hardly been convincing in a context of a lack of economic regulation at local level and the absence of democratic control. In a study on the impact of NPM in public services, Jensen and Stonecash (2005) highlight a reduction in costs following the transfer of management of public services to the private sector, regarding household waste collection, cleaning, transport, fire fighting, prison management and road maintenance. Average reductions of $20 \%$ have been announced for household waste collection (Domberger, Meadowcroft and Thompson, 1986) ${ }^{23}$, although placing public operators under contracts has also led to savings (17\%). In many cases, the introduction of competition has played a decisive role in the phenomenon of reducing costs, and this is what has been happening in recent years in France. Other analyses have shown that the average level of savings achieved ranges from 6 to $12 \%$ (Hodge, 1999). However, most of the time these situations have only been temporary: a monopolistic economic situation generates secure rent, generally to the profit of a private actor in a contractual framework in which the asymmetry of information remains the rule. Therefore the issue of the origin of the gains in efficiency obtained and their effects in the organisation remains open to debate on both theoretical and practical levels (Jensen and Stonecash, 2005).

\footnotetext{
${ }^{21}$ The action-research agreement in question also results in a commitment to develop a genuine cognitive approach to the local public action implemented.

${ }^{22}$ The main Australian governmental organisation in charge of performing studies on economic and regulatory policies, Waintrop et al, 2005, page 12 of the report.

${ }^{23}$ Mentioned by Jensen and Stonecash.
} 
As for the ABC method, apart from experiments carried out in the hospital sector described in the literature ${ }^{24}$, implementing this type of cost measurement approach in marketable public services is not very widespread in France, and even less so in the water sector.

In the new context of mixed management systems being implemented in the Greater Nantes public water service, although public and private operators are seen to obtain comparable results due to the service charter that harmonises the service rendered by them, the public water service must nonetheless set out the criteria that justify its performance from an economic point of view. For senior and political management, knowing the costs of the service it runs represents a new challenge in the face of increased demands for justifying the cost of the service rendered to the customer ${ }^{25}$. Indeed, for the reasons mentioned above (monopoly, lack of democratic), price is far from constituting an indicator of the system's economic performance. Furthermore, although it is clear that the precepts of public action at Greater Nantes exclude any reasoning in terms of profitability, taking into account the notion of efficiency reflects a dimension of performance hitherto ignored.

By introducing the cost between the public service rendered and its price, the city water service sets itself the goal of making the economic value of the public service visible. This is the only information that allows justifying the price of water economically and thus establishes the truth on prices and the idea of fair price.

\section{II - The conflict between tools. Between the mindsets of the technical citadel and the solution to societal challenges}

Among the performance management tools that have marked the management of the Greater Nantes public water service in the past, the quality approach counts as one of the tools with which its users have had the most significant experience. The introduction of the activities based costing tool (ABC) will obviously give rise to a comparison between the two tools due to the existence of a common denominator which is the notion of activity in both approaches. Since modelling the service's organisation is based in both cases on the definition of the service's key activities and their grouping into processes, the question of harmonising the two tools will be raised by the employees from the outset.

Consideration began internally between the group supervising the action-research, senior management (of the Water Service), middle management and operatives brought together for sessions of collective feedback and discussion on the new map of the activities. Two key problems in the management of public organisations, in terms of conceptual and analytical reasoning, were brought to light by two practical issues. The first questions the utility and meaning given to public action in the framework of the quality approach. The second raises in a more earthbound way the question of the performance objectives targeted by the new tool.

\section{1. The quality tool bears the seal of a technical vision of performance and consolidates the rationales inherent to the technical citadel}

Although initially the quality tool is designed as an instrument for measuring and managing performance in favour of the user, the rationale of its procedure in reality roots the content of service performance within a rationale of resources, thereby referring to a technical vision already pervasive in the service anchored to the operational stakes of performance. This is the observation that was to

\footnotetext{
${ }^{24}$ There is a fairly large amount of literature on the implementation of approaches to evaluate the economic performance of the public hospital sector based on the ABC-ABM method. Regarding this subject see Nobre T.(2003), Gosselin M. (2000), Arnaboldi M.\&Laspley I. (2004), Jones C. (1999), Doolin B.(1999).

25 Just recently $(2006,2007)$ a national consumer association -UFC Que Choisir- issued a document on the price and cost of water, generating an unprecedented controversy involving local authorities and private and public operators.
} 
emerge from the reflexive feedback on the stakes relating to the performance underlying the quality approach.

a) The procedural rationale of the quality system and the legitimation of the performance of the public service by a logic of resources.

Different studies carried out on management and labour sociology have shown the limits of management systems using ISO 9001 standards: Brown R. (1994), Savall H. et Zardet V. (1996), Cochoy F et all, 1996, 2002, Mispelblom F (1995), Neuville J.P (1996), Stevenson T.H \& Barnes F.C (2001), Lambert G. et al (2006), etc. The criticism concerns different levels: the clumsiness of the procedures and bureaucratisation, costs higher than expected profits, absence of real conviction from the actors in the field, the effect of managerial fashion, the exhibition of a label (certification) rather than seeking continuous improvement, etc. Critical analyses have highlighted the same phenomena in public organisations where these standards are being increasingly implemented ${ }^{26}$.

At RCE, one of the specific characteristics of implementing the quality tool which focuses on collective discussion carried out internally is its "procedural" logic in that the rationale at work depends on the processes used and not on the results to be reached (H. Simon, 1976). The standard in question demands the implementation and monitoring of a large number of organisational procedures designed to allow reaching the quality sought (Gendron et al, 2003). Thus certification concerns conformity with these procedures rather than the result itself. Conversely, substantive standards focus not on the resources to be deployed, but on the result or performance to be achieved. This procedural vision of the standard stems from a mechanistic perception of organisation composed of organisational routines whose management consists in applying the principles attached to them (Lambert G., Ouedraogo N., 2006) ${ }^{27}$.

In reality, this method of justifying performance based on resources is hardly novel in the running of the technical citadel.

\section{b) The quality tool reproduces the rationales of the technical citadel}

Several authors have defended the idea that performance management tools do not exist as such and that they were always a contextualised social construct (Latour B., 1992, Moisdon J-C., 1997). Furthermore, far from being neutral, performance management tools, often considered as the new attire of rationalised modern public action, only provided a logic of control over the operations carried out by organisations. In the case of RCE, the performance management tool initially designed in favour of an ignored user, bore the technical patina of the system to which it applied and merely consolidated the rationales inherent to the technical citadel.

Thus, although the logic of the quality model postulates that the performance of an organisation is appreciated by the yardstick of the product and its conformity with defined procedures, water quality objectives, continuity and safety have always been constants and a priority of the water service, and belong to this same approach of placing the "product" and "conformity with procedures" to the fore.

Obviously, the experience with measurements of most public organisations has shown that basic monitoring of activity (controlling operations and production) is almost always present. On the other hand, performance measurement tools that position an entity in relation to its aims and objectives by using more aggregated data than those collected at operational level are less widespread (Gibert P., 2000). This is precisely what was observed in the case of implementing the quality tool at RCE.

In reality, it appears that it is not the tool that imposes its instrumental rationale on the organisation, but rather the technical system that impregnates the tool with its rationale. All

\footnotetext{
${ }^{26}$ On the bibliographical level, the highest number of articles published dealing with management quality analyses concern the hospital sector .

${ }^{27}$ According to G. Lambert, this mechanistic and universalist vision of total quality is propagated in particular by quality "gurus" such as Deming (1988), Juran (1987) and Crosby (1986) who reason in terms of absolutes of quality.
} 
said and done, everything occurs as if the management of the technical citadel were autonomous. The managerial logic specific to this type of technical system appears to shrug off the procedural and formal requirements of the quality system.

J. Ellul highlights this phenomenon in his analysis of the "technical system" specific to the modern world where the principle of "autonomous technology" can be assimilated with a technocracy "that in the end only defends itself, that beats its own path, that is the prime factor..." (in Le système technicien, 1990, p. 137). "The digression of this technical regime characteristic of our era, -he adds- is that it overshadows the culture of meaning and values".

The other consequence resulting from the procedural digression attached to the quality tool is the ambiguity of referring to the customer as being at the heart of the discourse on performance.

c) The instrumentation of performance via quality tools only works to the advantage of a consumerist image of the user.

The second point marking the discussion begun in RCE when confronting quality tools and the $\mathrm{ABC}$ approach stems from the artificial nature of the "user-client" rhetoric that eclipses more in-depth debate on modern water management. Indeed, the debate on the status of the user in the formulation of public action is constantly open to both theoretical and practical interrogation.

Firstly, on the theoretical level, it has been established that the user of a public service cannot be simplified to being a "customer" (P. Warin, 1997, G. Jeannot, 1998). This consumerist vision of the user excludes the characteristic of "user-citizen", thus a member of the community and necessary for performing the democratic duties of public service. The setting up of local consultative commissions of users by virtue of the law of 1992 relating to the Territorial Administration of the Republic in the sector of water, is an example of this requirement. What is more, the rejection of customer-centrism runs parallel to the claim that water is an essential public good, for which the symbol of the customer represents a convenient diversion used by those in the system spurred by commercial interests.

Secondly, on a more formal level, it is accepted that using the symbol of customer as an argument for modernisation in a context of non regulated monopoly in which the user is a de facto captive lacks pertinence (M. Tsanga Tabi, 2003). Despite changing the name of the user of a public service, the issue of monopoly linked to price remains and there is no reason for proclaiming victory in the name of the user, since, as Dupuy F. (1998) says, "the genuine victory of the customer is the end of monopolies". In the case of implementing quality tools, the ploy of depicting the user as customer merely serves the argument that the user is nothing other than a consumer and omits the basic stakes underlying the problem, i.e. those of a "fair price for water" and community democracy.

Finally, implementing the quality tool at RCE will have the effect of making the management of the public water service more humdrum by promoting a vision of public service as nothing more than an ordinary saleable good and by reproducing the rationales at work in the technical system. Its confrontation with the new tool therefore leads the actors involved to review the situation in perspective and refine their reflection on the missions and performance objectives of the organisation.

\section{II.2. The performance of public service is positioned by its capacity to internalise the contemporary concerns of society in its management and to raise genuine public debate}

The experiment of confronting the management tools at RCE is interesting for our analysis as it takes into account a quest for performance that requires a shift in the angle from which the actors perceive the object constituting the public service. The angle changes from an approach that sees the public service as a technical object to one that sees the public service as a system of public action, in a context that permits removing the constraint of performance due to a situation of local monopoly. What new finalities for public services emerge in this new context? This question is far from 
innocuous as it is the first time that the senior management and employees of the service have been asked collectively to express a response. In parallel, it also examines the content in the performance of the service.

a) The introduction of the efficiency criterion in the management of the technical citadel and the new finalities of performance

Although measuring efficiency in the management of public water services is a new issue in France, a brief review of the managerial literature concerning the public sector reveals that the experience of measuring costs, and more generally the utilisation of performance management tools in local public services, is no recent phenomenon, especially in Anglo-Saxon countries. A series of surveys performed in the United States between 1976 and 1988 on management tools in local municipalities (Poister T.H, Streib G., 1989) highlighted a "boom in performance management tools" throughout the 1980s. Instruments such as management by objectives, performance board monitoring and program evaluations formed the basis of municipal management, while tools such as financial board monitoring, long term forecasting, strategic planning and quality circles were developed.

At RCE, the ABC project led to starting consideration on ensuring consistency between the new tool and all the organisation's measurement, auditing and control tools as well as with the other actionresearch projects ${ }^{28}$ in view to managing and evaluating "global performance". The aim is in particular to identify the basis of the operational and strategic activities that characterise modern water management skills and make it the core for auditing performance. A Quality-ABC harmonisation group was set up and the map of the activities and processes stemming from the ABC project was finally drawn up with the result or reducing the initial model of 21 processes to only 7 . The following diagram illustrates the new configuration given to the performance management tools.

Diagram 1: Reconfiguration of performance management tools relating to the integration of the ABC tool.

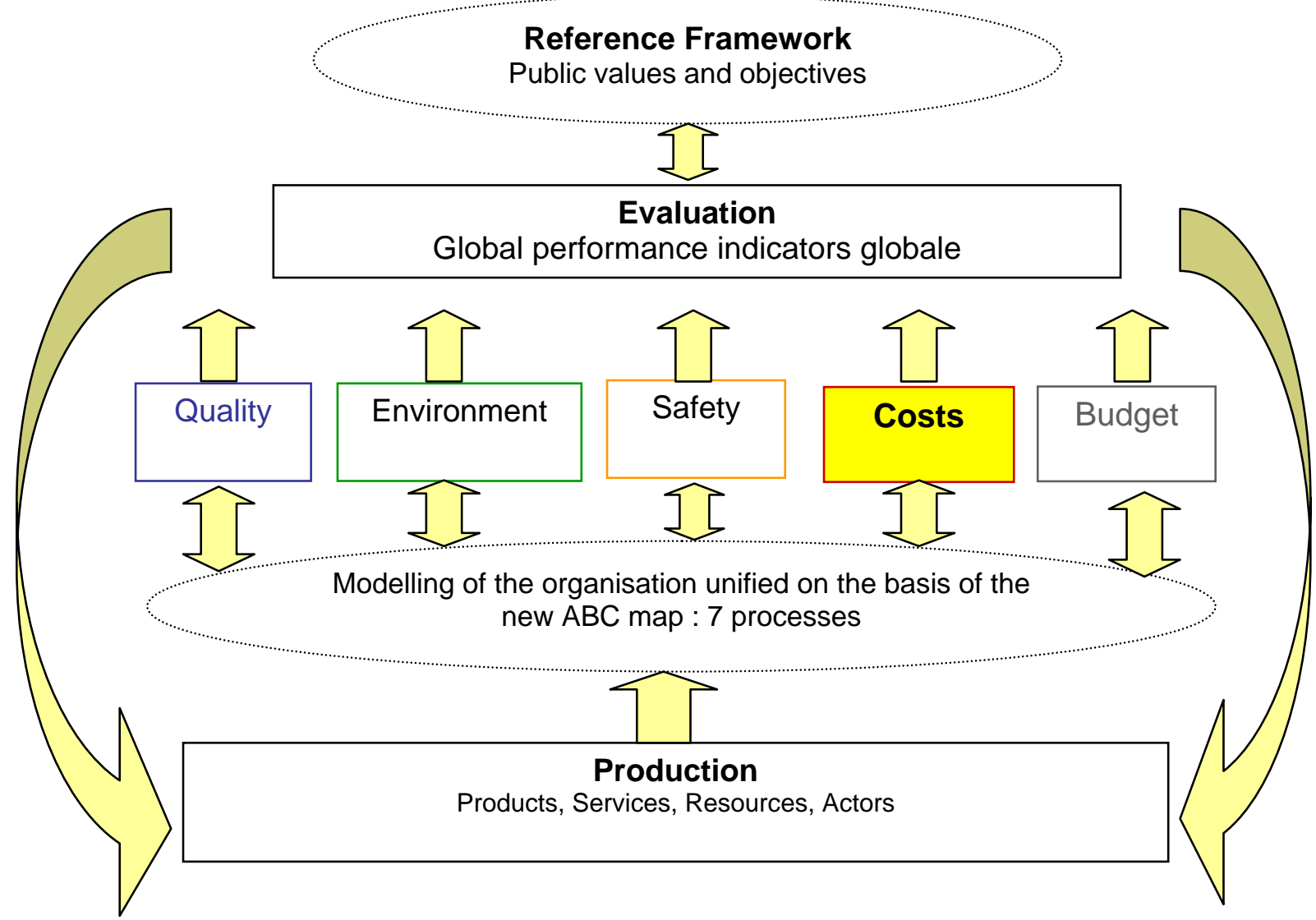

\footnotetext{
${ }^{28}$ In particular the "Public values of water" project
} 
As far as the service studied is concerned, although the quest for economic performance is appropriate in the context of water managed by private companies according to Anglo-Saxon free market economics and the French system of contracting out management, this is not at all the case for public water management. Financial profitability is not the overriding principle of the quest for performance, thus such services escape "systematic squeezing of resources" (Ruffat J., 2000). The goal of efficiency in this case encompasses technical, organisational, environmental and other stakes that cannot be boiled down into economic performance alone. However, beyond this issue one is obliged to conclude that the notion of economic performance and its associated objectives remains vague due to the diversity of the stakes and finalities involved.

Regarding the debate on the finalities of the new tool, it immediately led to the question of the identity and raison d'ettre of an organisation of a different type from the private companies operating in the territory. Thus for all the actors concerned, it is understood that the scope of action of public services fulfils another ideal, that of acting in the common interest. That being said they still cannot escape the economic rationale in the market environment that characterises water management. Consequently, it is necessary to define performance criteria that are specific to the type of management concerned. Analysis of the material resulting from interviews with employees and focus-groups has permitted identifying a certain number of finalities to be linked with the quest for economic performance. Three different scenarios have been established and their main elements are shown in the following table.

Table 1: New finalities linked to the quest for economic performance at RCE

\begin{tabular}{|l|l|l|}
\hline & \multicolumn{1}{|c|}{ Hypotheses of the scenarios } & \multicolumn{1}{|c|}{$\begin{array}{c}\text { New finalities linked to the quest for economic } \\
\text { performance }\end{array}$} \\
\hline Scenario 1 & $\begin{array}{l}\text { Knowledge of costs of the service } \\
\text { independently of measuring productivity }\end{array}$ & - knowing the fair price for water. \\
\hline Scenario 2 & $\begin{array}{l}\text { hypothesis of productivity gains highlighted } \\
\text { by measuring costs and maintaining water } \\
\text { prices }\end{array}$ & $\begin{array}{l}\text { - increasing employees' level of qualification } \\
- \text { dynamising relations with the user-citizen by } \\
\text { organising new missions intended to spur } \\
\text { community dialogue on local water } \\
\text { management (e.g. community workshops) }\end{array}$ \\
\hline Scenario 3 & $\begin{array}{l}\text { Hypothesis of productivity gains highlighted } \\
\text { by measuring costs and reductions of water } \\
\text { prices }\end{array}$ & $\begin{array}{l}\text { - price reductions for disadvantaged segments of } \\
\text { the public in view to providing them more } \\
\text { affordable access to water }\end{array}$ \\
\hline
\end{tabular}

The expected effects of internalising this new dimension of performance can be identified at several levels:

Firstly, on the cognitive level, highlighting the economic performance of management is in itself a goal insofar as current budgetary management fails to provide any visibility regarding costs, and this information is a prerequisite for calculating the "fair-price" identified as a new stake for the public service.

For the local authority, this knowledge participates in broadening the expertise linked to the function of regulating water management and to the reduction of the informational asymmetry that characterises the cost of delegated water management contracts.

Secondly, on the managerial level, the integration of a cost variable in the system appears to be a means of objectifying public decision making by politicians, in a context where investment decisions made by the service are mostly governed by the requirement for technical efficiency and zero risk in the water supply, subject to the sole political constraint of stabilising water prices.

The other change expected concerns the perception of this cost by the actors of the public water service who in fact are not directly concerned by it for the reasons already mentioned above (non visibility of cost and situations of local monopoly). Thus it entails making them more cost-conscious. Lastly on the socio-political level, the measurement of economic performance is considered as a variable capable of triggering genuine local debate, opening the way for a democratically inspired rationale and giving rise to pluralist evaluation. Likewise, taking into account the social dimension in 
the framework of a new pricing policy (scenario 3) opens the way to equity based on social justice, hitherto unexplored by the service.

Thus it appears that the chronology of management tools used at RCE results from a process of internalising the stakes of public water service performance differentiated through time. The following table summarises these differentiated stakes of performance related to the tools employed.

Table 2: Chronology of management tools used at RCE and the stakes related to performance.

\begin{tabular}{|c|c|c|}
\hline $\begin{array}{c}\text { Traditional tools centred on technical } \\
\text { objects }\end{array}$ & Quality approach & ABC approach \\
\hline $\begin{array}{l}\text { Issue of product and the stake of } \\
\text { conformity with regulations. } \\
\text { Issue of "access to service" and } \\
\text { stake of serving the territory. } \\
\text { Issue of managing existing } \\
\text { infrastructures and the stake of } \\
\text { maintaining them in good condition } \\
\text { through time. } \\
\text { Issue of choice of investment and } \\
\text { the stake of sizing the structures. } \\
\text { Issue of politically acceptable price } \\
\text { for water and the twofold stake of } \\
\text { recovering investment and operating } \\
\text { costs and ensuring social peace. }\end{array}$ & $\begin{array}{l}\text { Issue of customer satisfaction } \\
\text { and the stake of justifying a local } \\
\text { monopoly and a technical } \\
\text { citadel. } \\
\text { Issue of conforming to quality } \\
\text { procedures and the stake of } \\
\text { legitimisation through technical } \\
\text { efficiency. } \\
\text { Issue of the obligation of output } \\
\text { and the stake of objectifying the } \\
\text { criteria of the service rendered to } \\
\text { the user on the technical level. } \\
\text { Issue of participatory } \\
\text { management and the stake of } \\
\text { changing culture. } \\
\text { Issue of technical performance } \\
\text { indicators and the stake of } \\
\text { successfully carrying out } \\
\text { operational public action. }\end{array}$ & $\begin{array}{l}\text { Issue of efficiency and three stakes: } \\
\text { - the reality of costs and a fair price, } \\
\text { - the legitimisation of the non- } \\
\text { technical criteria of performance: } \\
\text { legitimisation through finalities and } \\
\text { values, } \\
\text { - justification and legitimisation of } \\
\text { public management options in the } \\
\text { context of mixed organisational } \\
\text { modes. } \\
\text { Issue of defining the objectives of } \\
\text { economic performance and the stake of } \\
\text { successfully carrying out strategic } \\
\text { public action. } \\
\text { Issue of extending managerial dialogue } \\
\text { to new performance criteria and the } \\
\text { stakes of getting the actors involved in } \\
\text { deploying the approach and the } \\
\text { supervision of global performance. }\end{array}$ \\
\hline
\end{tabular}

In the context of the action studied, originally, the management tools were designed to fulfil a managerial ideal aimed at satisfying the initial stakes of the public service of an operational nature, i.e. serving territories with drinking water, building infrastructures, etc. whose production is taken for granted in modern Western societies. Although this traditional model of action specific to technical systems constitutes the basis upheld for the performance of public water services, it is nonetheless true that the stakes linked to this performance change through time. This is in line with the evolution of societal needs and of the relations between the stakeholders of the service. The quality tool was brought in to respond to implicit stakes linked to the justification of a local monopoly and the legitimisation of a technical citadel. This is currently achieved by employing a customer centred approach in the service of technocentric rationalities and by taking into account the political need to ensure "trouble-free water prices".

Since they are intrinsically non-focused on technical stakes, the ABC tool and the approach of the action-research providing the framework for its implementation are utilised from a different standpoint. They initiate an approach to performance that legitimates other criteria : efficiency and fair price, service accessibility, the objectification of political decision-making, etc., that require clarification of the roles played by the actors. These concerns stem from new stakes that transcend the traditional vision of service performance and which underline a shift in restructuring local public action carried out in essential public services in France. 
Faced by the new challenges characterising the current context of the public water service management studied here, an internal workgroup called "global performance management" has been set up to consider the procedures for integrating these challenges in the management of the service. The definition of a performance termed "public" that emerges links the idea of performance to the capacity of the public service to respond to the contemporary social challenges it has to face. We shall see the new dimension given to management tools in the description of this requirement.

\section{b.1) "Public" performance characterised by its capacity to internalise contemporary social challenges}

Within the public service studied, the question of the finalities of the system and the associated performance objectives newly raised by the actors basically expresses the need for a new strategic position in a scope of action henceforth characterised by mixed organisational modes. The reflexive feedback on performance observed in the framework of our research and which causes senior management to take note of the increasingly humdrum nature of public water management procedures, leads to a new type of demand, that of the "publicness" (Gibert, P.1994, Bozeman B., 2002) of the performance of the public service. In other words, the question of performance raised here is that of the added-value provided by "public" water management of water in comparison to the "private" water management.

The partial responses given at this level of interrogation identify the added-value of public management as its capacity to respond to the societal stakes that characterise modern water management, i.e. its capacity to find a new balance between the traditional stakes of technical and market rationales and the new stakes presented further on.

\section{The stake of fair price and the social justice of the system}

The issue of social justice in the scope of managing the public sector and French doctrine on public service is not new in itself. Many authors have studied the issue on philosophical (Rawls J., 1987) and judicial levels (Duguit L., 1901, Hauriou M., 1927). What is new however in the case of the public service studied here, is the fact that this dimension of public action, until now absent from managerial concerns, seems to be a criterion necessary for justifying it and providing the hallmark of this mode of management.

In France, questions of social justice and equity in water management are linked to the idea of "fair price" for water ${ }^{29}$. This was the subject of public debate and an item in the reform of the water law and aquatic environments (LEMA) of December 2006. There is nothing innocuous about the notion of fair price for water in the case of public water services run by private companies since it results from the fierce conflict between "water as public property" and "water as a saleable commodity" that has marked water management at both national and international level for over two decades. Furthermore, due to the lack of transparency surrounding the price paid by water users, it is perceived as being both economically and socially unfair.

In the United Kingdom, where water management is privatised, the Citizen's Charter founded on the principles of New Public Management (NPM) has introduced a similar idea by underlining the status of citizen given to those benefitting from public services. Henceforth the citizen demands value for money and is "entitled to expect services of high quality, answering their needs and provided efficiently for a reasonable price” (The Citizen’s Charter, 1991).

\footnotetext{
${ }^{29}$ This question does not refer to equality here. In France, the concept of equality of access to the public water service is based on an objective difference of situation between users with respect to water consumption. This is the only justification for a difference in treatment, especially regarding price. Different prices can be applied to households, companies, shops and public organisations. Jurisprudence relating to water has confirmed this principle of discrimination between users more than once (rulings Vidal, 1981; Paraiso, 1983; Bachelet, 1991) (Mbacké Cissé F., 1996).
} 
For the actors of RCE, information on the cost of the public service rendered and its measurement are the only factors capable of bringing to light the economic value of the public service, thus justifying the price of water economically, establishing the truth on prices and the idea of fair price. This information also sheds light on "the much sought after monopoly rent" (Jean Ruffat, 2000) ${ }^{30}$ through productivity gains. This aspect of the question calls to mind a basic and as yet unresolved question in the water sector: that of regulating the rent.

Furthermore, the increased vulnerability of certain groups of the population further aggravated by rising water prices has resulted in an increase in the number of unpaid bills and reduced affordability of the service for a category of users. Although this information is not clearly visible for the city of Nantes, this issue has nonetheless become part of the debate on social justice.

The other dimension involved in reshaping how performance is perceived at RCE is that of the capacity of tools to stir public debate on water management.

\section{The stake of accountability: performance whose expression and measurement stir local public} debate

The second stake identified at RCE is the need to start dialogue on management with the citizens in view to making local water management more democratic.

This widened view of performance open to external reporting ${ }^{31}$, equivalent to accountability reports in Anglo-Saxon countries, is interesting as it goes beyond the logic of internal reporting. This approach is also perceived as the means of improving user consultation procedures.

In the United Kingdom, where performance measurement was introduced before the neo-conservative NPM movement proposed its own solutions, one of the main questions raised by the diffusion of performance indicators in the public service sector during the 1990s was their capacity to evaluate the outcomes of public action (Smith P., 1990). However, beyond the aspect of practices, accountability is one of the recurrent topics of debate on performance measurement in the public sector found in the literature. Regarding this, Brooks A-C. (2002) said that "accountability is certainly as relevant to the public sector as it is to nonprofits”.

Whatever the case, a new dimension of the performance measurement tool came into being, that of a use no longer strictly situated at the level of the technical regulation of the public service, but at that of the social and political regulation of local water management.

Lastly, the confrontation of management tools in the public service studied constitutes an interesting opportunity for providing constructive and useful criticism of existing measurement and analysis tools, finally obliging the actors to refine their questions regarding this performance. In a universe in which action is codified by legislation, regulations and the instrumental rationality governing it on a daily basis, there is a considerable risk of losing sight of the results hoped for. What is more, this task will have been an opportunity to prevent the insidious drifting of aims from their original intent, a subtle but ever present risk in the technical citadel. For the actors, the current redefinition of the content of performance also corresponds to a quest in search of the meaning to be given to the action carried out by large public services.

\section{III - Conclusions and outlook -}

The use of management tools in the urban public service sector brings to light the co-existence of two different types of instrumentation :

\footnotetext{
${ }^{30}$ Jean Ruffat “Le pari du hors-marché, De l’apesanteur en économie”, Economica, 2000, page 274.

${ }^{31}$ Information intended for the user-citizen and their representatives (municipal council in session: mayor, councillors, vice-chairmen, etc.)
} 
- The first is initial and structural. It belongs to the management of a public service perceived as a technical object where the budgetary and financial logic in play are based on the convenience gained by the context of natural monopoly. The dynamics of the system and the tools used reflect an almost automated mode of management strengthened by legal and regulatory measures that lead to an unparalleled level of codification and constraints.

It is this image of managerial instrumentation of urban public services that brings to mind the "technical citadel" that oversees public water services in which the management tools, "invisible pilots” of public action, invest a form of government by instruments (Lascoumes P., \&. Le Gales P, 2005). Nonetheless, this model of managerial instrumentation is not without consequence for the management of public organisations: it makes the management of public service more humdrum, leads to divisions as it ignores the political dimension and does nothing to solve the problem of the coherence and pertinence of the organisation as a whole.

- The second form of instrumentation that expresses the changes at work in urban public services, reflects a vision of public service not as a commodity or a good to be exploited, but as a medium for public action performed to respond to the challenges facing society. From this viewpoint, management tools (as in the case of the $\mathrm{ABC}$ tool) participate in a process of change that requires assistance and management of the organisational transformations to be made to match and satisfy societal needs. This quest for performance requires clarification and specialisation of the roles played by the stakeholders of the public service and especially the assertion of the role of the political actor. It is in this direction in particular that reflection on the triad "organising authority - operator - user-citizen" has begun at RCE.

Because these two images of the managerial structure reflect different outlooks on performances and instrumental rationales, they juxtapose more than harmonise with each other, and the experiment of confronting the two tools presented in this article makes it possible to highlight important information on the links between management tools and the quest for performance in the public sector.

Firstly, the implementation of quality tools in the public service studied revealed that the latter was not neutral and that its use in the technical citadel merely reproduced the rationales inherent in the service with respect to its technical dimension.

Secondly, it is symptomatic to observe in the case of the public service studied, that instrumental innovation was first considered as the solution for taking into account a new stake identified by the actors: new stakes demand new tools. Thus it appears that managerial instrumentation in the local public sector is done by steps, each step constituting a privileged moment for examining the usefulness of performance measurement tools and the finalities of the action. The example of the Nantes public water service expresses the wealth of analysis and its impact on performance that organising open debate on management tools can provide, leading to the positioning of the latter as a function of a progressive and negotiated construction of shared perceptions.

We began by asking the question: how can the performance of the public water service be defined? Our analysis shows that the model incorporating performance rooted in technical and commercial rationales and the specialised managerial instrumentation associated with it, cannot alone satisfy the modern requirements of public action. This is due to the risk of drift in the meaning of the action performed in the framework of this type of managerial system. The usefulness of management tools in the public sector can be identified more in their capacity to internalise the new societal stakes in play and account for the related global performance.

Nonetheless, it is obvious that our analysis does not exhaust the issue of managerial instrumentation and its relationship with performance in the public sector. The degree of openness of the political hierarchy, the personality of the managers and their sensitivity to the stakes of public action, the factor of time, the state of the balance of powers in play, the level of assimilation and acceptance of the tools by the actors are all factors requiring exploration. At times the new stakes that arise remain obscure to the actors of management and can come into conflict with their frames of 
reference. Although the motivation of the actors is essential, it is insufficient since the stabilisation of local public policy is also linked to the length of politicians' terms of office. In the case of NantesMétropole, it is evident that successive re-elections of the political team in place and the continuity of the management through time greatly contribute to promoting the transformations in progress at managerial level.

\section{REFERENCES}

Boussard, V. 2001. "Quand les règles s'incarnent, l'exemple des indicateurs prégnants." Sociologie du travail, 43, pp. 533-51.

Bozeman, B. 2002. "Public-Value Failure : When Efficient Markets May Not Do." Public Administration Review, 62:2, pp. 145-61.

Brooks, Arthur C. 2002. "Can Nonprofit Management Help Answer Public Management's "Big Questions"?" Public Administration Review, , 62:3, pp. 259-66.

Brown, R. 1994. "Does America need ISO 9000?",." Machine Design: 70-74.

Cochoy, F., J-P. Garel , and G de Terssac. 1998. "Comment l'écrit travaille l'organisation : le cas des normes ISO 9000." Revue française de sociologie, XXXIX:4, pp. 673-99.

Christen-Gueissaz, Corajoud Geneviève, Fontaine Michel, Racine Jean-Bernard (2006, sous la direction de) : Recherche-action, Processus d'apprentissage et d'innovation sociale, l'Harmattan.

Dejean, J., V. Bourassin, and K. Mortreux 1998. "Culture de l'évaluation et fascination pour les indicateurs." Revue Politiques et Management Public, 16:2, pp. 161-74.

Dente, B., P. Gibert, and E. Löffler. 2008. "De la qualité des services à la qualité démocratique : imaginer, évaluer et apprendre, conclusions des rapporteurs scientifiques." 5ème conférence sur la qualité des administrations publiques dans I'U.E: 29.

Detchessahar, M. and B. Journe. 2007. "Une approche narrative des outils de gestion." revue Française de Gestion, 174:5, pp. 77-92.

Duguit, L. 1901. L'Etat, le droit objectif et la loi positive (rééd).Dalloz 2003.

Dupuy, F. 1998. Le client et le bureaucrate: Dunod.

Ellul, J. 1977. Le système technicien. Paris.

Gadrey, J. 1995. "Eléments de socio-économie de la relation de service," in L'inscription sociale du marché (dir A. Jacob et H. Vérin). l'Harmattan ed. Paris, pp. 145-67.

Gadrey, J. 2001. Nouvelle économie, nouveaux mythes ? Paris: Flammarion,.

Gibert, P. 1994. " Ménager la publicitude." Ecole de Paris du management: Paris.

Gibert, P. 2000. "Mesure sur mesure." Revue Politiques et Management Public, 18:4, pp. 61-89.

Guellec, A. 1995. "Le prix de l'eau : de l'explosion à la maîtrise ?" Assemblée Nationale: Paris.

Haug, Peter. 2008. "Effects of " democratic control " on the efficiency of local public enterprises : empirical evidences for water suppliers in Eastern Germany." Public Finance and Management, 8:1, pp. 1-35.

Hauriou, M. 1927. « L'ordre social, la justice et le droit », Revue trimestrielle de droit civil, p. 795-825. Institut de Management Public, (2007), Journée d'étude du 28 novembre 2007, L'analyse des coûts dans le public : un équilibre impossible ? Paris

Hodge, G.A. (1999), "Competitive tendering and contracting out", Public Productivity \& Management Review, Vol. 22 No.4, pp.455-69

Jensen Paul H, Stonecash Robin E, (2004), The efficiency of public sector outsourcing contracts : a literature review, Melbourne Institute Working Paper $n^{\circ}$ 29/04, Australian Graduate School of Management, Melbourne Institute of Applied Economic and Social Research, University of Sydney and New South Wales, ISNN 1447-5863 (online)

Lambert, G. and N. Ouedraogo. 2006. "Normes, routines organisationnelles et apprentissage d'entreprise." La métamorphose des organisations, Nouvelles Régulations, Normalisation et Dynamique des Organisations: 29: Université de Nancy 2.

Latour, B. 1992. Aramis ou l'amour des techniques: La Découverte.

Lewin, K. (1951) Field theory in social science; selected theoretical papers. D. Cartwright (ed.). New York: Harper \& Row

Lorrain, D. 2005. "Les pilotes invisibles de l'action publique, Le désarroi du politique ?," in Gouverner par les instruments, P. Le Galès et P. Lascoumes (dir.). Presses Universitaires de Sciences-Po ed. Paris, pp. 163-95.

Mispelblom, F. 1995. Au-delà de la qualité, Démarches qualité, conditions de travail et politiques du bonheur. Paris: Syros.

Moisdon, J-C. (dir). 1997. Du mode d'existence des outils de gestion. Paris: Seli Arslan.

Muchielli, Alex (1991). Les méthodes qualitatives, Paris, P.U.F. (Que sais-je, no 2591) 
Muller, P. 2000. "L'analyse cognitive des politiques publiques : vers une sociologie politique de l'action publique." Revue française de science politique, 50:2, pp. 189-208.

Poister, Theodore H. and G. Streib. 1989. "Management Tools in Municipal Government: Trends over the Past Decade." Public Administration Review, 49:3, pp. 240-48.

Poister, Theodore H. and G. Streib. 1994. "Municipal Management Tools from 1976 to 1993: An Overview and Update." Public Productivity \& Management Review, 18:2, pp. 115-25.

Pollit, C. and G. Bouckaert. 1995. Quality Improvement in European Public Services. Concepts, Cases and Commentary. London.

Poupeau, F-M. 2001. "Libéralisation du service public et action publique locale. Le département dans la recomposition du système de distribution électrique français." Sociologie du Travail, , 43,:2, pp. 17996.

Rawls, J. 1987. Théorie de la justice.

Ruffat, J. 2000. Le pari du hors-marché, De l'apesanteur en économie: Economica.

Savall, H. and V Zardet. 1996. "A qui profitent les stratégies d'assurance qualité ? Essai d'analyse du partage de la valeur économique." Cinquième conférence internationale de management stratégique: Lille.

Segrestin, D. 1996. "La normalisation de la qualité et l'évolution de la relation de production." Revue d'économie industrielle, 75, pp. 291-307.

Simon, H. 1976. "From substantive to procedural rationality," in Models of bounded rationality. The free press ed. New York, pp. 424-43.

Smith, P;. 1990. "The use of performance indicators in the public sector." Journal of the Royal Statistical Society, 153:1, pp. 53-72.

Stevenson, T. H. and F. C. Barnes. 2002. "fourteen years of ISO 9000 : impact, critiscism, costs and benefits." Business Horizon: 45-51.

Tsanga Tabi, M. 2003. "Théorie et réalité du service public local : le cas de la distribution d'eau potable." thèse de doctorat en sciences de gestion: 780. Université de Paris X: Paris.

Tsanga Tabi, M. 2004. "La place du développement durable dans le nouveau référentiel des services publics d'eau potable - Débats autour de l'évaluation des services publics marchands," in $L a$ dynamique de l'évaluation face au développement durable (dir C. Ossredi). L'Harmattan ed. Paris: Société Française de l'Evaluation, pp. 151-63.

Tsanga Tabi, M. and D. Verdon. 2008. "L'élu, le manager et l'usager : nouveau triptyque de l'évaluation de l'action publique locale. L'expérience d'une régie communautaire de l'eau," in $L e$ citoyen, l'élu, l'expert, Pour une démarche pluraliste d'évaluation des politiques publiques. L'Harmattan ed. Paris: Société Française de l'Evaluation, pp. 42-52.

Tsanga Tabi, M., D. Verdon, and M. Campardon. 2007. "Quelle définition de la performance économique des services publics en régie ? Récit d'une tentative de " republicisation " du service public : le cas de la régie communautaire de l'eau de Nantes-Métropole." 16ème colloque international de la "Revue Politiques et Management Public ": 14: Florence, Italie.

Ughetto, P. 2006. "La performance publique entre l'économique et le politique. Le cas des musées." Politiques et Management Public, 24:1, pp. 55-78.

Varone, F. and S. Jacob. 2004. "Institutionnalisation de l'évaluation et nouvelle gestion publique : un état des lieux comparatifs." Revue Internationale de Politique Comparée, 11:2, pp. 271-92.

Waintrop F., Chol C., Girardin O., Maréchal M., 2005. La performance à tous les coûts : l'expérience de six pays, Institut de la gestion publique et du développement économique, $11 \mathrm{p}$ 